\title{
RETROACTIVITY: PARAMOUNT POWERS AND CONTRACTUAL CHANGES
}

\author{
GUIDO GALABRESI +
}

WHILE the constitutionality of retroactive laws has been much discussed by courts and commentators, ${ }^{1}$ one situation has received relatively little treatment. This is the situation arising when a law is passed which alters the effect of existing contractual obligations of the federal government. That this problem has received little treatment is quite understandable. The constitutional issue it poses is unique in that it might be viewed as anterior to that of the "fairness" of the retroactive law, and to concern the very different problem of the source of the government's power to alter its obligation. Most commentators, have devoted their attention to the meaning of "fairness" in the context of retroactivity, and accordingly have not paused to examine the question of power. ${ }^{2}$ Yet it is worthy of some discussion, not only because it sheds interesting light on an area where the Court might properly hold a close rein on the activities of Congress, but also because the last time the issue came up-in F.H.A.v. The Darlington, Inc. ${ }^{\text {- }-i t ~ r e c e i v e d ~ a ~ q u i t e ~ u n s a t i s f a c t o r y ~}$ judicial treatment.

The Darlington case emerged from the incredible muddle of ill-drawn laws that constitute the National Housing Act. In 1949 Darlington, Inc., a South Carolina corporation, was formed to build an apartment house in Charleston. It expected and received F.H.A. mortgage insurance to aid it in financing the project. At the time the applicable section of the Housing Act, section 608, contained no language expressly providing that buildings subject to federally

$\dagger$ Associate Professor of Law, Yale University Law School.

I should like to thank Keith Rosen, a second year student at the Yale Law School for his help on the footnotes. He bears no responsibility, however, for whatever thought or depth is missing from this Comment.

1. See, e.g., Hochman, The Supreme Court and the Constitutionality of Retroactive Legislation, 73 HARv. L. REv. 692 (1960) ; Slawson, Constitutional and Legislative Considerations in Retroactive Lawnaking, 48 CALIF. L. REv. 216 (1960).

2. Thus, for example, both Hochman, supra note 1, and Slawson, supra note 1, are concerned with demonstrating, through examinations of the factors which courts appear to weigh in these cases, that "fairness" is the ultimate test of the validity of retroactive laws. Both authors bypass questions of the sources of legislative power to enact such laws, simply assuming the power exists subject to due process limitations.

3. 358 U.S. 84 (1958). 
insured mortgages could be used only for residential purposes. ${ }^{4}$ Despite this omission, it was relatively clear that the act was aimed at residential buildings; the history of the act left little doubt, and regulations issued under the act unequivocally provided, that mortgaged property should be "designed principally for residential uses." Nevertheless, neither the regulations, nor the charter of the corporation, nor the contract of insurance for the mortgage expressly barred Darlington from occasionally renting to transients.

Unfortunately for Darlington, the apartment building did not prosper. Indeed there is evidence that had the corporation not started to take in transients, bankruptcy and default of the mortgage would have been inevitable. Only by renting to transients rooms which were not desired by permanent residents was the company able to make a profit. Unlike some other companies in similar positions, it was not able to get formal F.H.A. approval of this practice. Approved or not approved, occasional transient rentals continued.

In 1954 Congress enacted a law declaring that the National Housing Act precluded the use of buildings subject to federally insured mortgages "for transient or hotel purposes" and had done so from the very beginning." The new law, nevertheless, went on to provide that, whatever the law had been prior to 1954 , no building, whether new or previously built, which was subject to a federally insured mortgage, could now be used for transient purposes unless the F.H.A. had agreed in writing before May 28, 1954, to allow such use. ${ }^{7}$ Congress was goaded into passing this law by irate representatives of the hotel industry who claimed that they were being injured by

4. The section merely provided, in pertinent part:

...

(b) To be eligible for insurance under this section a mortgage shall meet the following conditions:

(1) The mortgaged property shall be held by a mortgagor approved by the Commissioner. The Commissioner may, in his discretion, require such mortgagor to be regulated or restricted as to rents or sales, charges, capital structure, rate of return, and method of operation....

(2) Preference or priority of opportunity in the occupancy of the mortgaged property for veterans of World War II and their immediate families, and for hardship cases as defined by the Commissioner, shall be provided under such regulations and procedures as may be prescribed by the Commissioner ....

56 Stat. 303 (1942), as amended, 12 U.S.C. § 1743 (1958).

5. Development of property. At the time the mortgage is insured the mortgagor shall have constructed and completed or shall be obligated to construct and complete new housing accommodations on the mortgaged property designed principally for residential use, conforming to standards satisfactory to the Commissioner and consisting of not less than eight (8) rentable dwelling units on one site and may be detached, semidetached, or ranchhouses, or multifamily structures.

13 Fed. Reg. 8260 (1948) (repealed Dec. 18, 1958).

6. Housing Act of $1954, \S 513,68$ Stat. 610,12 U.S.C. $\$ 1731 \mathrm{~b}$ (1958).

7. The bill also barred any criminal penalties for violation of the no transient provision which had occurred before the effective date of the new law. 68 Stat. 611,12 U.S.C. $\S 1731 b(d)$ (1958). If Congress' interpretation of the pre-1954 law were correct, rental to 
"apartment house-hotels" cheaply financed through government insured mortgages under section 608. The hotel industry had brought to Congress' attention tales of enormous profits which allegedly had occurred in such government backed "hotels"- tales which Congress was rather inclined to believe in view of the general history of windfall profits under section 608 of the Housing Act. $^{8}$

Armed with the 1954 law, the FHA began to make life difficult for Darlington, and the latter promptly sought a declaratory judgment justifying its rental practices. Darlington argued that neither the pre-1954 law, nor any valid regulations under it barred occasional rentals to transients so long as the company operated the property "principally" for residential use and so long as it made apartments available to anyone who wanted them for extended, nontransient use. The company further contended that the 1954 law itself was unconstitutional for any of half-a-dozen reasons, beginning with its retroactive nature and ending with its alleged discriminatory effect. ${ }^{9} \mathrm{~A}$ three judge district court ${ }^{10}$ agreed with Darlington in most essentials and allowed limited rentals to transients.

On appeal the Supreme Court reversed by a five-to-three vote, Justice Stewart taking no part. The majority opinion written by Justice Douglas was

transients would of course have been a criminal offense all along. But perhaps Congress sensed due process objections would be made to convicting a person under a statute which gave so little warning of the offense.

8. See, e.g., 100 CoNG. REc. 12333, 12355 (1954) (remarks of Senator Capehart).

9. Darlington's principal arguments against the constitutionality of the 1954 amendment were: (1) the amendment was retroactive legislation abridging vested rights and, therefore, was in violation of the 5th amendment; (2) the law was enacted for the private benefit of members of the American Hotel Association and arbitrarily and unreasonably discriminated against Darlington; (3) Congress can act only for a valid public purpose and the 1954 amendment furthered no public purpose.

10. The tangled history of the case in the lower court is perhaps worth noting. When the case first came before him, District Judge Hoffman asked that a three-judge court be convened because injunctive relief against enforcement of an Act of Congress was sought on the ground that the act was unconstitutional. 28 U.S.C. $\$ 2282$ (1958). The three judge court concluded that the pleadings presented only a question of statutory construction and that the pleadings also failed to disclose a case where an injunction would be the proper form of relief. It, therefore, dismissed itself. 134 F. Supp. 337 (E.D.S.C. 1955).

After the three-judge court had dissolved itself, Judge Hoffman, sitting alone, proceeded to find that Darlington had a right to make occasional rentals to transients before 1954 and that the 1954 amendment could not retroactively take away the right. Judge Hoffman further indicated his distaste for the 1954 amendment by finding it discriminatory in that it was designed to relieve private interests and excepted resort areas such as the state of Florida for no apparent reason. 142 F. Supp. 341 (E.D.S.C. 1956).

The F.H.A. appealed directly to the Supreme Court which reversed the original order of the three-judge court on the ground that the complaint had in fact stated a claim for injunctive relief restraining enforcement of an Act of Congress on a constitutional issue and that therefore a three judge court was needed. 352 U.S. 977 (1957). On remand from this per curiam opinion, a three-judge court reconvened, substantially adopted Judge Hoffman's original opinion, and thereby paved the way for another F.H.A. appeal. 154 F. Supp. 411 (E.D.S.C. 1957). 
based on two essentially independent grounds. The first was that the Housing Act, before the 1954 law was passed, implicitly if not explicitly barred rental to transients. Had the Court said no more, Darlington would be a case of very minor importance, decided on a dubious reading of statutes and regulations, but warning builders that the enormous gaps and inconsistencies in housing laws could work against as well as for them. This ground alone would have accomplished-albeit gracelessly-what after all had been the major aim of Congress all along.

The difficulty with Darlington is that the court did not stop there. The second part of the majority opinion stated that whatever the exact meaning of the law before 1954 may have been, Congress' 1954 act settled the matter. Justice Douglas quickly dismissed the constitutional issue. In his view, even if the pre-1954 law did not bar rentals to transients it certainly raised enough doubts about them to preclude anyone from gaining a "vested right" to such rentals. Moreover, he considered the housing industry so subject to government control- "regulation" was the word used-that anyone operating in it must expect further, prospective controls to be applied to what could be done with existing buildings. To call such controls unconstitutionally retroactive, added Mr. Justice Douglas, in what seemed almost a peroration, would be to cause the ghost of Lochner ${ }^{11}$ to rise again.

There were two dissents from the Court's opinion. Justice Frankfurter, though joining Justice Harlan's longer opinion, added a few words of his own. After reiterating his extreme reluctance to hold a law unconstitutional, the Justice stated that the real question was whether the rights involved were vested and that precedent compelled him to find that they were. No discussion of the precedents cited or of the possible precedents going the other way on the issue of "vestedness" was given. ${ }^{12}$ As to any other questions, the Justice referred to Mr. Justice Harlan's opinion.

That opinion, in which Justice Whitaker also joined, was in many ways the most interesting of the three. It began with a quick and assured rejection of the Court's reading of the pre-1954 law. The original Housing Act and regulations may very well have failed to give the right to rent to transients, said the Justice, but they just as clearly did not bar such rentals. And that in fact was the issue, since builders, like everyone else, are free to do what they like

11. Lochner v. New York, 198 U.S. 45 (1905).

12. Justice Frankfurter simply cited three cases: Fleming v. Rhodes, 331 U.S. 100 (1947) (legislation retrospectively abrogating eviction judgments which landlords had obtained during a 25 day gap in the Emergency Price Control Act held valid); Paramino Lumber Co. v. Marshall, 309 U.S. 370 (1940) (private act of Congress authorizing review of a workman's compensation award which had become final through expiration of time for review held not to violate due process to the employer); Lynch v. United States, 292 U.S. 571 (1934) (congressional act rescinding war risk insurance contracts held invalid as an impairment of vested rights). One can only conclude that he felt Darlington's rights more akin to those of the holders of policies in the Lynch case than to the employer's right in the finality of the arbitration award in Paramino or the right of a landlord in the eviction judgments in Rhodes. But why he felt that way was not explained. 
with their property unless they either contract away that right or some law excludes a particular use. Having disposed of that issue, Justice Harlan attacked the 1954 law. The problem here, the Justice said, was whether Congress could by a new law increase the obligations assumed by Darlington in its 1949 contract with the government. If Congress were acting under some general regulatory power, the new restrictions on Darlington might well be valid. But Congress could not, merely because of its contractual relationship with Darlington, alter its contract with the company. In reaching this conclusion Justice Harlan relied on the earlier Supreme Court rulings in Lynch v. United States $^{13}$ and Union Pacific Railroad Company v. United States. ${ }^{14}$ These cases, he said, indicated that unless a paramount federal power, apart from power to make contracts, supported a change the government was bound to its agreement. The fact that it is sovereign does not increase its rights under a contract any more than the fact that there is a contract limits the government's sovereignty. ${ }^{15}$ The question, then, as viewed by Justice Harlan, was not so much one of the validity of retroactive legislation, but of the source of the federal power to alter an existing contract.

The opinion indicated that if it had been some military necessity, for example, which had required the barring of transients from buildings constructed with federal help, Justice Harlan would have had no trouble upholding the law involved in Darlington. The war power would have required the change, and the language of Lynch that the government could not contract away its rights as sovereign would seem clearly in point. ${ }^{16}$ One would expect therefore that the majority in Darlington would have emphasized some paramount power which required and justified the alteration of the contract. Instead, the power to "regulate" seems simply to have been assumed. Yet it is hard to

13. 292 U.S. 571 (1934).

14. 99 U.S. 700 (1878) (the "sinking fund" cases).

15. When the United States enters into contract relations, its rights and duties therein are governed generally by the law applicable to contracts between private individuals.

292 U.S. at 579.

The United States are as much bound by their contracts as are individuals. If they repudiate their obligations, it is as much repudiation . . . as it would be if the repudiator had been a state or a municipality or a citizen.

99 U.S. at 719.

On the other hand, public and general acts of the federal government will be upheld as valid although they may collaterally alter specific contracts. See, e.g., Horowitz v. United States, 267 U.S. 458 (1925). For related issues arising from state impairment of contracts see Home Bldg. \& Loan Ass'n v. Blaisdell, 290 U.S. 398 (1934).

16. As Congress had the power to authorize the Bureau of War Risk Insurance to issue them [i.e., insurance contracts], the due process .clause prohibits the United States from annulling them, unless, indeed, the action taken falls within the federal police power or some other paramount power.

292 U.S. at 579. See also Lichter v. United States, 334 U.S. 742 (1948) (act requiring wartime government contractors to renegotiate their contracts held a valid exercise of the war power). 
escape the conclusion that if there is any problem with the Darlington case, it must be on the ground that what Darlington was doing did not affect an area sufficiently subject to federal power and interest, and not that the law which sought to circumscribe Darlington's rental practices was unfairly retroactive. Indeed, the fascinating thing about Darlington is that as recently as three years ago three members of the Court could find no positive federal power to support a change in a contract dealing with housing-and that if but one other Justice sitting had agreed with them, an act of Congress would have been voided-while the majority were so little troubled by the issue that they did not even bother to discuss it. From all this one must assume that the majority was either rejecting Justice Harlan's view that a paramount power is necessary to alter a federal contract or that it had in mind a paramount federal power so obvious as to require no mention.

Both of these possibilities deserve examination. What would it mean to reject Justice Harlan's view that a paramount power is necessary? Before this question can be answered, some discussion of the source of the government's power to contract is needed. ${ }^{17}$ In the first place, the government can make contracts that are necessary and proper for the carrying out of any of the specific clauses of the Constitution. A contract to buy rifles under the war power might be an example. But apart from these specific sources, another more general source of the power to contract seems to exist in the power to tax and spend for the general welfare. The history of this power and the long polemic on whether the power to spend for the "general welfare" is limited to what is needed for the carrying out of some specific power, or whether it comprehends anything which works for the general good, need not be discussed here. ${ }^{18}$ It is enough to note that the latter, broader meaning has predominated for expenditure as well as taxation, and that with it has come the right to make contracts regulating the activities of those who would receive the tax money expended. ${ }^{19}$ Thus, for the public welfare, and by contract linked to expenditures, Congress can do a fair amount of controlling in areas beyond its specific limited powers. ${ }^{20}$

17. Early cases and commentators were willing to uphold the power of the federal government to enter contracts as simply an incident of sovereignty. See, e.g., United States v. Tingey, 30 U.S. (5 Pet.) 114 (1831) ; 2 Story, CommentarIes on the Constitution $\S 1256$, at 148 (5th ed. 1891). It would seem preferable to regard the broad capacity to enter contracts as authorized by the necessary and proper clause or the power to spend for the general welfare, for it has been held that the federal government has no inherent or sovereign powers other than those specifically or explicitly granted to it by the Constitution. See, e.g., Martin v. Hunter's Lessee, 14 U.S. (1 Wheat.) 304 (1816) ; Kansas v. Colorado, 206 U.S. 46 (1906). But see Dennis v. United States, 341 U.S. 494 (1951).

18. See, e.g., Lawson, The General. Welfare Clause (1926) ; Nicholson, The Federal Spending Power, 9 Texple L.Q. 3 (1934); Corwin, The Spending Power of Congress-A Propos the Maternity Act, 36 Harv. L. Rev. 548 (1923).

19. Compare United States v. Butler, 297 U.S. 1, 65-66 (1936), with Steward Mach. Co. v. Davis, 301 U.S. 548 (1937), and Helvering v. Davis, 301 U.S. 619 (1937).

20. It is hardly lack of due process for the Government to regulate that which it subsidizes.

Wickard v. Filburn, 317 U.S. 111, 131 (1942). See also Ivanhoe Irrigation Dist. v. McCracken, 357 U.S. 275 (1958) ; Ellis v. United States, 206 U.S. 246 (1907). 
Indeed, this was the way the Attorney General justified the original Housing Act of 1938.21 But where the government regulates by contractual agreement, it can not alter the rules except as the contract itself provides. At least, this is the meaning of the rule in Lynch as interpreted by Harlan in Darlington. The power to spend for the general welfare may well support a contract, but some other power is needed to impose a new contract or a change in the contract.

There is, however, no logical necessity about this analysis. One could argue just as plausibly that the very "general welfare" power which supported the contract allows the government to change it, if it is necessary for the common good. If the original contract did not accomplish the aims for which the money was to be spent, then Congress may certainly pass laws to see to it that the money does what it was meant to do. Is not this "necessary and proper" to the power to spend? Nor does this sanction injustice, the argument would run. For the government will always be limited by the due process clause and by the prohibition against the taking of property without just compensation. Thus the retroactive effect of such a law could be controlled, just as it would be if Congress found it necessary-because of war-to alter the rights of people with whom it had contracted in peace time. Under this reasoning all of Justice Harlan's doubts become meaningless. The test is, as the Court implied, one of fairness. And who is to say that, giving great deference to Congress, the 1954 law shocks the conscience, especially in view of the history of section 608 ? This meaning of Darlington quietly buries the notion that a precise paramount power is necessary.

Such a burial may give no cause for mourning if the only reason for the paramount power rule is to ensure that the government act according to due process standards, for the due process clause is quite up to that task without the rule. And-after all-the Lynch case is not so clear or uncontradicted that it cannot be bypassed. ${ }^{22}$ But the rule has more to it than that, and it is for this reason that one must hesitate before reading Darlington as destroying it. A1terations of government contracts are not desirable in a free country, even when they do not constitute a "taking" of property or impinge on questions of fundamental fairness of the type comprehended in due process. The government may make changes, but only if war or commerce require them and

21. 38 Ops. Atr'y Gen. 258 (1935), noted in 4 Geo. WasH. L. Rev. 144 (1935).

22. Finding the existence of a paramount power is, of course, one means of avoiding the holding in Lynch. Cf. Lichter v. United States, 334 U.S. 742 (1948). The Lynch case leaves open still another portal for congressional escape from its holding - sovereign immunity from suit. Justice Brandeis, the author of the opinion, suggests an ambiguous dichotomy between "rights," which Congress cannot alter without the support of a paramount power, and "remedies," which presumably may be altered with impunity:

... Congress retained power to withdraw the consent [to be sued] at any time. For consent to sue the United States is a privilege accorded; not the grant of a property right protected by the Fifth Amendment.... [I]mmunity from suit is an attribute of sovereignty which may not be bartered away.

292 U.S. at $581-82$. 
not on the broader and more ephemeral grounds that the general welfare would be served by the change. Any other rule would allow the government to welch almost at will. So viewed, the principles of $L y n c h$, if not its exact language, serve a distinct purpose. And while these principles could, of course, be comprehended under a general due process test ${ }^{23}$-due process can be made to incorporate anything if one wishes hard enough-clarity of thought might suggest that retaining a limitation such as that implicit in Lynch might be more desirable.

How then, if one is to save part of the paramount power rule, can Darlington be explained? The other alternative mooted-that the change in Darlington was in fact supported by an obvious paramount federal power-must be considered. The power which springs most directly to mind is, of course, commerce. It would not be difficult to find in the commerce power-"broad as the economic needs of the nation"24_-rather than in a conglomeration of individual contracts, the source of much of the federal intervention in the field of housing. But that is not quite the issue. For to satisfy the demands of the dissenters, the commerce power must support not housing legislation generally but the particular change in the particular contract. And the dissenters evidently are loath to see how it did that in Darlington.

Still, with a little imagination a relationship between the contract alteration and interstate commerce can be found. ${ }^{25}$ It can, in fact, be found in one of Darlington's principal arguments for the law's invalidity. For the company contended that the law was passed solely to help the hotel industry and, "therefore," was discriminatory legislation. Yet I can hardly doubt that if Congress expressly found that hotels needed subsidies to survive, and that the survival of hotels was essential to interstate commerce, a law granting such subsidies would not only avoid the taint of discrimination, but would also find so solid a backing in the commerce power that hardly any objection would be heard in the Court. And I have very little doubt that if, instead of giving a direct subsidy, Congress ordered that all buildings built with substantial government aid stop competing with hotels which had received no such aid, this law, too, would not be unconstitutionally discriminatory. It is equally hard to doubt the basis in the commerce power for such a law. The question then would reduce itself to whether the law was unfairly retroactive or constituted a taking of property-questions which the Court presumably met with sufficient force in Darlington.

Yet one cannot avoid the feeling that there is something fishy in all this. If the issue were so simple, why would the Darlington case have come out the other way with but one changed vote? And why would Justices Frankfurter

23. See text accompanying note 37 infra. Cf. Hochman, supra note 1.

24. Stern, The Commerce Clatse and the National Economy, 1933-1946, 59 HARv. L. Rev. 645, 883, 944 (1946). Cf. North.Am. Co. v. SEC, 327 U.S. 686, 705 (1946).

25. Indeed, the ingenuity required is considerably less than that displayed by the same Justice Harlan in finding support for the doings of Congress in the recent case of Flemming v. Nestor, 363 U.S. 603 (1960). 
and Harlan, usually so dedicated to carrying out the will of Congress-at almost any cost-have been so ready to void the 1954 law? The fishiness, of course, is that Congress did not expressly link what it was doing to the commerce power. It did not say that hotels were in dire need, or that the need presented a danger to interstate commerce, and neither did the Housing Administration. As Justice Harlan put it,

I do not understand the Housing Administration to contend that the United States possesses general regulatory power over appellee outside the contractual relationship, and the Court has pointed to no such "paramount power" by which the imposition of the 1954 Act's prohibitions might be justified in this case. ${ }^{26}$

But is it necessary that Congress or the Housing Administration spell out the connection with commerce? Could not the Court, or the dissenters themselves, make the link? For it would be the height of absurdity to force Congress in every case to specify-by lofty preamble no doubt-that it is acting under a particular power (subject to the penalty of having the law voided if it either used inappropriate language, or picked the wrong power). This surely cannot be the result that the dissenting Justices desired. ${ }^{27}$

But we must not be so hasty in branding what the dissenters seemed to be looking for as absurd. To say that Congress had to make the link between interstate commerce and what it was doing in Darlington is not to say that Congress has to specify the power it is using, and why it is using it, in every case. For Darlington involves two elements which may make congressional specification desirable. In the first place, the connection between commerce and the contract change, while possible, is not obvious. It requires stretching the commerce power to its boundaries, albeit boundaries it has reached before. There would be nothing odd for the Court in such a case to refuse to look for a power which could be made to support the change. It could say instead that it is true that the power might come from the commerce clause, but we will not read the clause so broadly unless Congress-which is in possession of more facts than we and which is responsible to the electorate-goes out on a limb and says that the law is necessary because commerce demands it. In this way the electorate is told clearly and directly why a step is taken and can judge for itself whether Congress acted wisely. ${ }^{28}$

26. 358 U.S. at 98.

27. It is possible to read the Butler case, in the light of Wickard v. Filburn, as one where Congress picked the wrong power. See note 20 supra. But there are so many dubious explanations of the Butler case that it hardly seems worthwhile suggesting another. In any event, the Court quite often has diligently searched for a power in order to uphold a congressional act. See, e.g., Perez v. Brownell, 356 U.S. 44 (1958) ; United States v. Curtiss-Wright Corp., 299 U.S. 304 (1936); Mackenzie v. Hare, 239 U.S. 299 (1915). But cf. Carter v. Carter Coal Co., 298 U.S. 238 (1936); Civil Rights Cases, 109 U.S. 3 (1883).

28. See Bickel, Foreword: The Passive Virtues, 75 HARv. L. REv. 40 (1961); Bickel \& Wellington, Legislative Purpose and the Judicial Process: The Lincoln Mills Case, 71 Harv. L. REv. 1 (1957). 
Analogies for such a decision in prior cases before the Supreme Court are easy to find. Thus, in United States v. Yellow Cab Co. ${ }^{29}$ the Court, though it had before it decisions that the Sherman Act reached as far as the commerce power could extend, refused to apply the law to cabbies plying their trade between hotels and railroad stations in the same city. It noted, however, that if Congress expressly wanted the act to cover this activity and drew the link with commerce, such a law might well be valid. ${ }^{30}$ More recently, the Court has on several occasions refused to follow what, in terms of statutory interpretation, was clearly the will of Congress where to do so would violate traditional liberties of the people. ${ }^{31}$ In taking this step the Court did not say that Congress could not act that way. Nor did it say that Congress did not intend the result prohibited. It said instead that if Congress wanted a result which so stretched its powers, it had to say so clearly and unequivocally, so that the electorate might know who was responsible for the law. What the dissenters wanted in Darlington may, then, have been exactly this. ${ }^{32}$

In Darlington, the dissenters could well say, there is every reason to force Congress to spell out the relationship of the 1954 law to a "paramount" federal power. The law, after all, altered a contract. And if the rule against altering contracts without a good and specific reason beyond a vague general welfare is to have any meaning, then the link between the change and the specific power must be either obvious or made so by appropriate congressional findings. If the Court were allowed to ramble all over in search for a "paramount" power which might fit, then it would be as well to face the facts and say that whenever the "general welfare" demands a change in a contract it can be made. All this, of course, brings us back to the fact that in Darlington the link was not obvious and required some stretching of the "paramount" power. It also brings us back to the fact that the Court's opinion is virtually no help in explaining just what the Court meant to be doing in the case.

Some readings of the Court's opinion can, however, be found which would allow us to live with Darlington and still save important elements of the paramount power concept. In the first place one must recognize that there is a crucial difference between the type of contract alteration which troubled the Court in Lynch and Union Pacific and the change which occurred in Darlington. For the fear expressed in the earlier cases stemmed from a concern with the effect on the people of the government welching on its obligations-alter-

29. 332 U.S. 218 (1947).

30. Id. at $232-33$.

31. See, e.g., Greene v. McElroy, 360 U.S. 474 (1959) ; Kent v. Dulles, 357 U.S. 116 (1958). Cf. Peters v. Hobby, 349 U.S. 331 (1955). But see Barenblatt v. United States, 360 U.S. 109, 134, 137-40 (1959) (dissenting opinion of Mr. Justice Black).

32. Justice Douglas, as the author of Kent v. Dulles, 357 U.S. 116 (1958), is certainly aware of the argument that in cases where the power of Congress is stretched, Congress itself should do the stretching. But to him and to Justice Black it may well be that commerce is so broad as never to require stretching. Cf. United States v. Yellow Cab Co., 332 U.S. 218 (1947). If so, the failure to worry over the link in Darlington may be understandable, but the alteration of contract aspect of the opinion remains to be explained. 
ing a contract for its own benefit. ${ }^{33}$ And it was this fear which engendered the rule that a paramount power, a good and sufficient reason for the change, was needed to support any contract alteration. Darlington, one can readily see, is quite another kettle of fish. Instead of benefiting the government financially, the alteration in contract terms jeopardized its situation. Since it had insured Darlington's mortgage, the government had everything to gain from Darlington's continued solvency, and everything to lose from its bankruptcy. ${ }^{34}$ The contract change made it difficult for Darlington to stay in the black; the case can hardly be termed one of government welching. And if it isn't a case of welching, is it really so terribly important to put obstacles beyond those of due process fairness in the way of government alteration of the contract? Indeed, one might almost assume that if the government chose to pass a law altering its own contract where the alteration brought it no gain, it must have had a reason founded either in the "general welfare" or in some "paramount power," whether or not Congress specified the grounds in passing the law. For otherwise, why should it have acted?

Here then lies a possible explanation for Darlington, though admittedly one which the Court does not give in its opinion. In fact here lie two possible readings of Darlington, which, though closely related, retain some differences. The

33. In $L_{y n c h}$, for example, the Court seemed primarily concerned with the motive of Congress:

... Congress was without power to reduce expenditures by abrogating contractual obligations of the United States. To abrogate contracts, in the attempt to lessen government expenditures, would be not the practice of economy, but an act of repudiation.

292 U.S. at 580.

The Court employed similar language in refusing to allow Congress to modify a gold bond of the United States and declaring the Joint Resolution of June 5, 1933, taking the United States off the gold standard, unconstitutional :

By virtue of the power to borrow money "on the credit of the United States," the Congress is authorized to pledge that credit as an assurance of payment as stipulated, as the highest assurance the government can give, its plighted faith. To say that the Congress may withdraw or ignore that pledge is to assume that the Constitution contemplates a vain promise.... This Court has given no sanction to such a conception of the obligations of our government.

Perry v. United States, 294 U.S. 330, 351 (1935). But cf. the right-remedy distinction in Lynch, supra note 22.

34. According to the findings of the District Court, all the parties concerned would end up losing money because of the contractual alteration: Darlington would default on the mortgage and lose its equity in the property; the government, as insurer of the mortgage, would have to pay the mortgagee the difference between the amount of the mortgage and the amount realized at a foreclosure sale; and since the building could not be run profitably as an apartment house, the only logical course would be to convert it into a hotel-a development that would give the Charleston hotel operators even stiffer competition. 142 F. Supp. at 350 .

Situations could be imagined where the legislative change would bring offsetting gain to the government as well as immediate financial loss. There is no evidence in the record that this was the case in Darlington. 
first reading is more in accord with Justice Harlan's view of Lynch. No contract change can be made unless a specific power outside the power to spend for the general welfare supports the change. Moreover, if the contract change benefits the government, Congress will be required to spell out why the change is required and what power requires it. If, instead, the change is not to the government's financial advantage, then the Court will be free to presume-as it may be said to have done in Darlington and as it does for most laws-that the change was required by commerce, war or whatever specific power seems to fit. $^{35}$ Of course, if no power at all can be found, the law altering the contract will fall. But a connection, even as tenuous as the one in Darlington, might well suffice. ${ }^{36}$ It would naturally be open to those challenging the law to show that the possible connection was not realistic. But the road would not be made easier just because a change in a government contract was involved.

The second reading, while inconsistent with Justice Harlan's views, seeks to accomplish many of the same objectives. Rather than requiring a paramount power to alter a contract, Darlington could be taken as admitting that the general welfare-the expenditure power-itself can back a change. But general welfare means something more than benefiting the government financially. And indeed, the existence of financial benefit to the government creates a suspicion, if not a presumption, that the change was attempted solely for that reason. Thus, when the government benefits from the change, a good and sufficient other reason is needed before the change will be upheld-a reason not necessarily grounded in the specific powers of the government but at least based on a notion of "general welfare" which excludes the justification that it benefits the government's purse. And Congress must spell out the reason so that the Court can judge for itself whether Congress is welching or genuinely acting for the public good. If, instead, the change does not help the government financially, the presumption is that the law was passed for the general welfare and no spelling out of reasons by Congress is needed. The change, of course, is still subject to due process standards but need meet no other more stringent tests.

35. This reading would incorporate the normal presumption in favor of the legislature: ... the existence of facts supporting the legislative judgment is to be presumed, for regulatory legislation affecting ordinary commercial transactions is not to be pronounced unconstitutional unless in the light of the facts made known or generally assumed it is of such a character as to preclude the assumption that it rests upon some rational basis within the knowledge and experience of the legislators.

United States v. Carolene Prods. Co., 304 U.S. 144, 152 (1938) (opinion of MIr. Justice Stone).

36. Of course, this reading and the readings which follow in the text do not meet the argument that the commerce power was being stretched so much in Darlington that Congress should have specified the connection between a paramount power and the contractual change. But where commerce is concerned-after and perhaps because of the fall of the old court-this argument may be viable in only the most extreme cases. See note 32 stipra. In any event the Yellow $C a b$ and Kent $v$. Dulles line of cases has already survived an accasional deviation. Compare Barenblatt v. United States, 360 U.S. 109, 134, 137-40 (1959) (dissenting opinion of Mr. Justice Black), with Greene v. McElroy, 360 U.S. 474 (1959). 
Under either of these readings, the Darlington decision can be reconciled with the retention of substantial control by the Court over attempts by the government to alter contracts for its own financial benefit. But each has some substantial disadvantages. The first reading would uphold laws altering contracts-even where the government benefited financially-so long as Congress made a connection with a paramount power and the change neither constituted a taking nor was so unfair as to violate due process. The fact that the needs of the paramount power were relatively slight and the unfairness involved relatively great would not matter. On the other hand, this reading might lead to the invalidation of a desirable change which caused practically no unfairness, merely because Congress failed to mention a specific power and some slight financial gain occurred. Worse, it might void a change which substantially served the general welfare and added nothing to the governmental coffer, but-mirabile dictu-could be attached to no specific federal power. In other words, this reading might give the court desirable power with one hand, but take away equally desirable flexibility with the other.

The second reading has the advantage of being more flexible. Contract changes may be upheld so long as no financial benefit accrues to the government even though no link to a particular power exists. More important, even if financial benefit exists, a positive connection by Congress between the change and some need of the general public apart from the money saved will validate the law. But even this reading makes it difficult to take into account some relevant factors. The degree of fairness involved-so long as it stops short of due process levels-is ignored. The extent to which the government is lining its own pockets and the strength of the needs of the general welfare are not weighed. The rule remains, to a substantial extent, mechanical.

Of course, more flexibility could be read into these rules. Each of the relevant factors could be weighed. But then the Court would be applying a test indistinguishable from due process. More consideration than is usual might perhaps be given to the factor of governmental "welching" for financial benefit, but the method of decision would involve the same balancing of unbalanceables. If this is done, it would seem best to erase the thin line of distinction and employ due process directly. After all, due process itself can take into account the problems implicit in government benefit from unilateral changes of contracts and balance them against the needs of the particular paramount power or of the general welfare, all the while spicing the mixture with a good dose of the unfairness to the parties involved. Indeed, due process better than either of the readings suggested can rank the paramount powers and thus evaluate the need for changes in a government contract.

If this be the case, why not use due process? The answer is not easy to verbalize. If I believed that the Court was ready to overturn financially-motivated alterations in federal contracts under the due process clause, I would think that test by far the most desirable. But the recent history of due process -especially, but not exclusively, in economic affairs-provides scant cause for 
comfort. $^{37}$ It is too easy when one balances everything to decide that one can evaluate nothing. And the frustration inherent in such a situation often leads to the abrupt conclusion that Congress knows best. The law is upheld, and perhaps flexibility has been bought at too high a price. For flexibility which leads to inaction may well be worse than rigidity which occasionally goes wrong but brings about desirable results in most cases.

The majority opinion in Darlington underscores the danger. Concerned as he is with the broad concept of fairness, Justice Douglas examines none of the specific factors that would seem crucial. Perhaps the result he reaches is the proper one for the case. I am inclined to think so, essentially because of the lack of financial motivation in the government's contractual change. But it is hard to escape the conclusion that Justice Harlan, though wrong, came far closer to the important issues before the Court, simply because his frame of reference was the specific and rather rigid one of the existence of a paramount power.

37. See, e.g., Fleming v. Nestor, 363 U.S. 603 (1960) ; Levine v. United States, 362 U.S. 610 (1960). Cf. Beilan v. Board of Education, 357 U.S. 399 (1958) ; Nelson v. County of Los Angeles, 362 U.S. 1 (1960). 